\title{
PENGARUH TINGKAT INFLASI, SUKU BUNGA DAN KURS VALUTA ASING TERHADAP RETURN SAHAM PADA PERUSAHAAN PROPERTY AND REAL ESTATE DI BURSA EFEK INDONESIA PERIODE 2012-2016
}

\author{
Putu Widya Putra Adnyana ${ }^{1}$, Kadek Rai Suwena ${ }^{1}$, I Nyoman Sujana ${ }^{2}$ \\ Jurusan Pendidikan Ekonomi \\ Universitas Pendidikan Ganesha \\ Singaraja, Indonesia
}

e-mail: widyaputraadnyana@gmail.com ${ }^{1}$, kadek_suwena@yahoo.co.id ${ }^{1}$, sujanatbn@yahoo.com ${ }^{2}$

\begin{abstract}
Abstrak
Penelitian ini bertujuan untuk mengetahui pengaruh tingkat inflasi, suku bunga dan kurs valuta asing secara parsial dan simultan terhadap return saham pada sektor property and real estate di Bursa Efek Indonesia pada periode 2012-2016. Berdasarkan jenis datanya, penelitian ini merupakan penelitian kuantitatif. Populasi dalam penelitain ini adalah semua perusahaan sektor property and real estate yang terdaftar di BEl periode 2012-2016 sebanyak 49 perusahaan. Sampel ditentukan dengan menggunakan metode purposive sampling dengan kriteria-kriteria antara lain perusahaan property and real estate yang terdaftar di BEI pada periode 2012-2016 dan memiliki data laporan keuangan yang berkaitan dengan variabel penelitian sehingga diperoleh sampel sebanyak 30 perusahaan di sektor property and real estate. Sumber data yang digunakan dalam penelitian ini diperoleh dari Indonesian Capital Market Directory tahun 2012 - 2016. Hasil menunjukkan bahwa secara parsial tingkat inflasi tidak berpengaruh signifikan terhadap return saham, suku bunga tidak berpengaruh signifikan terhadap return saham dan kurs valuta asing berpengaruh signifikan terhadap return saham. Secara simultan tingkat inflasi, suku bunga dan kurs valuta asing berpengaruh signifikan terhadap return saham.
\end{abstract}

Kata kunci: return saham, tingkat inflasi, suku bunga, kurs valuta asing

\begin{abstract}
This study aims to determine the effect of inflation rate, interest rates and foreign exchange rates partially and simultaneously to stock returns on property and real estate sector in Indonesia Stock Exchange in the period 2012-2016. Based on the type of data, this research is a quantitative research. Population in this research is all company of property and real estate sector listed in BEI period 2012-2016 as many as 49 companies. The sample is determined by using purposive sampling method with criteria such as property and real estate companies listed in BEl in period 20122016 and have financial statement data relating to research variablel so that obtained a sample of 30 companies in the property and real sector estate. Sources of data used in this study were obtained from Indonesian Capital Market Directory in 2012 2016. The results show that partially inflation rate does not have a significant effect on stock returns, the interest rate has no significant effect on stock return and foreign exchange rate has a significant effect on stock return. Simultaneously the inflation rate, interest rates and foreign exchange rates have a significant effect on stock returns.
\end{abstract}

Keywords : stock return, inflation, interest rate, foreign exchange rate 


\section{PENDAHULUAN}

Bisnis property and real estate baik residensial maupun komersial menunjukkan perkembangan yang cukup pesat di Indonesia. Semakin pesatnya sektor properti ini diikuti dengan semakin tingginya permintaan akan kebutuhan papan, sehingga membuat emiten-emiten properti membutuhkan dana dari sumber eksternal. Dana dari sumber eksternal masyarakat yang menginvestasikan modalnya di industri properti dikarenakan harga tanah yang cenderung naik. Penyebabnya adalah supply tanah bersifat tetap sedangkan demand akan selalu besar seiring pertambahan penduduk.

$$
\text { Sebelum investor mulai }
$$

menanamkan dananya atau menaruh saham di sektor yang ada di Bursa Efek Indonesia, investor haruslah mengetahui kinerja perusahaan yang ada dalam sektor tersebut. Menurut Hartono (2008) salah satu cara yang bisa digunakan dalam menilai perusahaan adalah pendekatan fundamental. Pendekatan tersebut terutama ditunjukan kepada faktor-faktor yang pada umumnya berada diluar pasar modal, yang dapat mempengaruhi harga saham di masa mendatang. Hal-hal yang termasuk dalam analisis fundamental antara lain adalah analisis ekonomi dan industri, penilaian perusahaan secara individu baik dengan menggunakan variabel penelitian seperti deviden maupun pendapatan (income) (Hartono, 2008).

Investor yang akan melakukan investasi dengan membeli saham di pasar modal akan menganalisis kondisi di dalam perusahaan maupun yang ada diluar perusahaan. Memperoleh return (keuntungan) merupakan tujuan utama dari aktivitas perdagangan para investor di pasar modal. Para investor menggunakan berbagai cara untuk memperoleh return yang diharapkan, baik melalui analisis sendiri terhadap perilaku perdagangan saham, maupun dengan memanfaatkan sarana yang diberikan oleh para analisis pasar modal, seperti broker, dealer, dan manajer investasi. Pola perilaku perdagangan saham di pasar modal dapat memberi kontribusi bagi pola perilaku harga saham di pasar modal tersebut.
Return saham merupakan hasil yang diperoleh dari kegiatan investasi. Return dibedakan menjadi dua, yaitu return realisasi (return yang terjadi atau dapat juga disebut sebagai return sesungguhnya) dan excepted return (return yang diharapkan oleh investor) (Jogiyanto, 2008). Harapan untuk memperoleh return juga terjadi dalam assets financial. Suatu assets financial menunjukkan kesediaan investor menyediakan sejumlah dana pada saat ini untuk memperoleh sebuah aliran dana pada masa yang akan datang sebagai kompensasi atas faktor waktu selama dana ditanamkan dan risiko yang ditanggung. Dengan demikian para investor sedang mempertaruhkan suatu nilai sekarang untuk sebuah nilai yang diharapkan pada masa mendatang. Menurut Halim (2005:34) return saham terdiri dari dua komponen utama yaitu Capital Gain, dan Yield. Komponen pertama dari return adalah Capital gain, yaitukeuntungan bagi investor yang diperoleh dari kelebihan harga jual di atas harga beli yang keduanya terjadi di pasar sekunder. Komponen kedua yield, yaitu pendapatan atau aliran kas yang diterima secara periodik misalnya berupa deviden atau bunga.

Investor dalam assets financial juga mengharapkan return yang maksimal. Harapan untuk memperoleh return yang maksimal tersebut diusahakan agar dapat terwujud dengan mengadakan analisis dan upaya tindakan-tindakan yang berkaitan dengan investasi dalam sahamnya. Oleh karena itu, perlu diketahui faktor-faktor yang mempengaruhi return saham sehingga harapan untuk memperoleh return yang maksimal bisa dicapai.

Menurut Samsul (2006: 335) terdapat banyak faktor yang mempengaruhi return saham baik yang bersifat makro maupun mikro ekonomi. Faktor makro ada yang bersifat ekonomi maupun non ekonomi. Faktor ekonomi makro terinci dalam beberapa variabel ekonomi misalnya inflasi, suku bunga, kurs valuta asing, tingkat pertumbuhan ekonomi dan harga bahan bakar minyak. Non ekonomi mencakup peristiwa politik, sosial dan hukum. Sementara itu, faktor mikro ekonomi terinci dalam beberapa variabel, 
misalnya laba per lembar saham, deviden per saham, nilai buku per saham.

Menurut Sukirno (2008:14), inflasi didefinisikan sebagai suatu proses kenaikan harga-harga yang berlaku dalam suatu perekonomian. Tingkat inflasi berbeda dari satu periode ke periode lain dan berbeda pula dari satu negara ke negara lain. Samuelson \& Nordhaus (2001) memberikan definisi bahwa inflasi sebagai suatu keadaan dimana terjadi kenaikan tingkat harga umum, baik barang-barang, jasa-jasa maupun faktor produksi. Dari definisi tersebut mengindikasikan keadaan melemahnya daya beli yang diikuti dengan semakin merosotnya nilai riil (intrinsik) mata uang suatu negara. Inflasi merupakan kecenderungan terjadinya peningkatan harga produk-produk secara keseluruhan. Tandelilin (2010:342) inflasi yang tinggi mengurangi tingkat pendapatan riil yang diperoleh investor dari investasi. Sebaliknya, jika tingkat inflasi suatu negara mengalami penurunan maka hal ini merupakan sinyal yang positif bagi investor seiring dengan turunnya risiko daya beli uang dan risiko penurunan pendapat riil. Menurut Samsul (2006:201), bahwa inflasi yang tinggi akan menjatuhkan harga saham di pasar. Sementara inflasi yang rendah akan berakibat pertumbuhan ekonomi yang sangat lamban dan pada akhirnya harga saham juga bergerak dengan lamban.

Selain inflasi, suku bunga juga dapat dikatakan mempengaruhi return saham. Suku bunga SBI (Sertifikat Bank Indonesia) pada prinsipnya adalah surat berharga yang dikeluarkan oleh Bank Indonesia sebagai pengakuan utang jangka pendek dengan sistem diskonto atau bunga. Sunariyah (2006:80) suku bunga adalah harga dari pinjaman. Suku bunga dinyatakan sebagai presentase uang pokok unit waktu. Menurut Kasmir (2005:224), SBI merupakan surat berharga yang diterbitkan oleh Bank Indonesia (BI). Menurut Cahyono (2000:117), terdapat dua penjelasan mengapa kenaikan Suku Bunga dapat mendorong Return Saham kebawah. Pertama, kenaikan suku bunga mengubah peta hasil investasi. Kedua, suku bunga akan memotong laba perusahaan. Kenaikan suku bunga akan meningkatkan beban emiten, sehingga labanya bisa terpangkas. Selain itu, biaya produksi akan meningkat dan harga produk akan lebih mahal sehingga konsumen akan menunda pembeliannya dan menyimpan dananya di bank. Penurunan penjualan perusahaan dan laba akan menekan return saham karena para investor lebih memilih menanamkan uangnya pada deposito bank saat tingkat suku bunga sedang naik. Sebaliknya, bila suku bunga sudah melemah maka para investor akan kembali beralih pada saham. Dalam penjelasan tersebut dapat, disimpulkan bahwa jika tingkat suku bunga tinggi maka return saham akan mengalami penurunan dan sebaliknya.

Faktor lain yang turut berpengaruh pada tingkat pengembalian saham adalah kurs valuta asing. Menurut Suta (2000), terjadinya apresiasi rupiah memberikan dampak terhadap perkembangan pemasaran produk Indonesia di luar negeri terutama dalam persaingan harga. Apabila apresiasi rupiah terjadi maka secara tidak langsung akan memberikan pengaruh terhadap neraca perdagangan, karena menurunnya nilai ekspor dibandingkan dengan nilai impor. Seterusnya, akan berpengaruh pula kepada neraca pembayaran Indonesia. Memburuknya neraca pembayaran tentu akan bepengaruh terhadap cadangan devisa. Berkurangnya cadangan devisa akan dapat mengurangi kepercayaan investor terhadap perekonomian indonesia, yang selanjutnya menimbulkan dampak negatif terhadap perdagangan saham dipasar modal yang dapat berupa anjloknya harga saham dan mengakibatkan berkurangnya tingkat pengembalian saham. Depresiasi rupiah menyebabkan sumber dana mengalir dari pasar saham ke arah pasar uang asing. Investor akan menginvestasikan dananya pada pasar uang asing karena dinilai lebih memberi keuntungan.

Kenyataannya, tidak semua teori yang telah dipaparkan di atas sejalan dengan bukti empiris yang ada. Seperti yang terjadi dalam perkembangan sektor property and real estate yang terdaftar di BEl periode 2012-2016. Adapun besarnya 
rata-rata return saham industri real estate and property yang terdaftar di BEI pada tahun 2012-2016 nampak pada tabel 1 : 
Tabel 1. Rata-rata Return Saham, Inflasi, Tingkat Suku Bunga dan Kurs Valuta Asing Industri Real Estate and Property di BEI Tahun 2012-2016

\begin{tabular}{|c|c|c|c|c|c|}
\hline Keterangan & 2012 & 2013 & 2014 & 2015 & 2016 \\
\hline Return Saham & $42,44 \%$ & $3,20 \%$ & $55,76 \%$ & $-6,47 \%$ & $5,47 \%$ \\
\hline Inflasi & $4,3 \%$ & $8,4 \%$ & $8,4 \%$ & $3,4 \%$ & $3,0 \%$ \\
\hline Tingkat Suku Bunga & $5,77 \%$ & $6,48 \%$ & $7,54 \%$ & $7,50 \%$ & $6,50 \%$ \\
\hline Kurs Valuta Asing & 9.670 & 12.189 & 12.440 & 13.795 & 13.436 \\
\hline
\end{tabular}

Sumber: Statistik Ekonomi Keuangan Indonesia, IDX

Berdasarkan tabel 1 terlihat bahwa perkembangan return saham sektor property and real estate yang terdaftar di Bursa Efek Indonesia periode 2012-2016 mengalami fluktuasi. Besarnya return saham tertinggi terjadi pada tahun 2014 sebesar $55,76 \%$, sedangkan return saham terendah terjadi pada tahun 2015 sebesar $-6,47 \%$. Berdasarkan Tabel 1 juga terlihat bahwa Inflasi, Tingkat Suku Bunga, dan Kurs Valuta Asing menunjukkan kondisi yang tidak konsisten dengan return saham pada sektor property and real estate yang terdaftar di Bursa Efek Indonesia periode 2012-2016. Pada tahun 2014 sampai dengan tahun 2015 tingkat inflasi mengalami penurunan yang sangat besar dari tahun sebelumnya yaitu sebesar $5 \%$, selanjutnya pada tingkat suku bunga dari tahun 2014 sampai 2015 juga ikut mengalami penurunan sebesar 0,04\%, sedangkan pada return saham yang seharusnya mengalami kenaikan pada tahun 2014-2015 pada kenyataannya malah mengalami penurunan. Disamping itu kurs valuta asing yang terus mengalami kenaikan setiap tahunnya, pada return saham tidak konsisten mengikuti kenaikan kurs valuta asing tersebut.

Beradasarkan latar belakang tersebut maka, penulis ingin melakukan penelitian yang berjudul pengaruh inflasi, suku bunga, kurs valuta asing terhadap return saham pada sektor property and real estate yang terdaftar di bursa efek indonesia periode tahun 2012-2016.

Adapun tujuan dari penelitian ini adalah untuk mengetahui pengaruh tingkat inflasi, suku bunga dan kurs valuta asing secara parsial dan simultan terhadap return saham pada sector property and real estate di Bursa Efek Indonesia pada periode 2012-2016.

\section{METODE}

Penelitian ini merupakan penelitian asosiatif yaitu penelitian yang bertujuan untuk mengetahui pengaruh ataupun juga hubungan antara dua variabel atau lebih (Sugiyono, 2012). Oleh karena itu, penelitian ini bertujuan untuk mengetahui pengaruh variabel independen terhadap variabel dependen dan seberapa kuat pengaruh tersebut. Berdasarkan jenis datanya, penelitian ini merupakan penelitian kuantitatif, yaitu penelitian yang datanya berbentuk angka (Sugiyono, 2012).

Populasi dalam penelitian adalah seluruh perusahaan property and real estate yang terdaftar di Bursa Efek Indonesia (BEI) yang berjumlah 49 perusahaan. Untuk menentukan sampel dalam penelitian ini, peneliti menggunakan metode nonprobability sampling dengan teknik purposive sampling yang merupakan teknik pengambilan sampel berdasarkan kriteria tertentu yang ditentukan oleh peneliti (Sugiyono, 2012:122). Kriteria yang telah ditentukan adalah perusahaan property and real estate yang terdaftar di BEI selama periode tahun 2012-2016. Perusahaan property and real estate yang menyediakan data laporan keuangan yang lengkap dan telah diaudit selama periode 2012-2016. Berdasarkan kriteria tersebut, maka sampel dalam penelitian ini sebesar 30 perusahaan.

Teknik pengumpulan data dalam penelitian ini menggunakan metode dokumentasi. Data yang digunakan dalam penelitian ini adalah data sekunder yaitu data yang diperoleh bukan langsung dari sumbernya. Dalam penelitian ini data bersumber dari laporang keuangan yang berasal dari Indonesian Capital Market 
Directory (ICMD), IDX Statistic, dan situs resmi Bank Indonesia (www.bi.go.id).

Teknik analisis yang digunakan untuk menyelesaikan permasalahan dalam penelitian ini adalah Regresi Linier Berganda dengan menggunakan bantuan program komputer SPSS 22 (Statistical Package for Social Science). Metode regresi linier berganda digunakan untuk mencari hubungan dan pengaruh dua variabel atau lebih. Teknik analisis ini digunakan untuk menguji hubungan dan pengaruh tingkat suku bunga, inflasi dan kurs valuta asing terhadap return saham pada perusahaan property and real estate yang terdaftar pada Bursa Efek Indonesia (BEI) secara parsial. Menurut Nata Wirawan (2002:293) persamaan linier berganda adalah sebagai berikut.

$Y=b_{0}+b_{1} X_{1}+b_{2} X_{2}+b_{3} X_{3}+b_{4} X_{4}+e$ Keterangan :

$$
\begin{array}{ll}
\mathrm{Y} & =\text { Return Saham } \\
\mathrm{b}_{0} & =\text { Bilangan Konstanta } \\
\mathrm{X}_{1} & =\text { Tingkat Inflasi } \\
\mathrm{X}_{2} & =\text { Tingkat Suku Bunga } \\
\mathrm{X}_{3} & =\text { Kurs Valuta Asing } \\
\mathrm{b}_{1}-\mathrm{b}_{3} & =\text { Koefisien regresi variabel } \\
\mathrm{e} & =\text { error atau residu }
\end{array}
$$

Analisis regresi linier berganda terdapat dua jenis pengujian yaitui uji t dan uji F. Uji statistik t digunakan untuk mengetahui seberapa besar pengaruh satu variabel independen terdiri dari tingkat inflasi (X1), suku bunga (X2) dan kurs valuta asing (X3) secara individual menjelaskan variabel terikat yaitu return saham (Y). Uji statistik $F$ dalam penelitian ini digunakan untuk mengetahui kemampuan variabel bebas (independen) yang terdiri dari tingkat inflasi (X1), suku bunga (X2) dan kurs valuta asing (X3), secara bersama-sama dalam menjelaskan variabel terikat (dependen) yaitu return saham (Y). Selain uji $t$ dan uji $F$, juga dilakukan analisis asumsi klasik yaitu uji normalitas, uji multikolinearitas, uji heteroskedastisitas dan uji autokorelasi.

Uji normalitas dilakukan untuk menguji apakah dalam sebuah model regresi, residu atau variabel penganggu dari persamaan regresi mempunyai distribusi normal atau tidak normal. Model regresi yang baik adalah yang memiliki distribusi normal atau mendekati normal (Ghozhali, 2011:160). Wibowo (2012:62) uji normalitas dapat dilakukan dengan menggunakan Histogram Regresion Residual yang sudah distandarkan, analisis Chi Square dan menggunakan Nilai Kolomogorov-Smirnov. Uji multikoliniearitas bertujuan untuk menguji apakah model regresi ditemukan adanya korelasi antar variabel bebas (Gozhali, 2011:105). Ada atau tidaknya multikolinearitas atau korelasi antar variabel bebas, dapat dilihat dari cut off nilai telorance atau Variance Information Faktor (VIF). Uji heteroskedastisitas betujuan menguji apakah terjadi ketidaksamaan varian dari residual satu pengamatan model regresi (Wibowo, 2012:93). Ada atau tidaknya heteroskedastisitas dapat menggunakan model Park Gleyser. Uji autokorelasi bertujuan untuk mengetahui apakah dalam model regresi linier ada korelasi antara keselahan pengganggu pada periode $(t)$ dengan kesalahan pengganggu pada periode sebelumnya $(t-1)$.

\section{HASIL DAN PEMBAHASAN
Pengaruh Inflasi Terhadap Return Saham Pada Sektor Property and Real Estate

Uji statistik t-tes pada program SPSS 22 for windows digunakan oleh peneliti

\begin{tabular}{|c|c|c|c|c|c|c|}
\hline & Model & $\begin{array}{l}\text { Unstanc } \\
\text { Coeffi }\end{array}$ & $\begin{array}{l}\text { ardized } \\
\text { ients }\end{array}$ & $\begin{array}{l}\text { Standardized } \\
\text { Coefficients }\end{array}$ & $\mathrm{t}$ & Sig. \\
\hline & & $\mathrm{B}$ & Std. Error & Beta & & \\
\hline 1 & (Constant) & 89,846 & 30,879 & & 2,910 & ,004 \\
\hline & Inflasi & 253,950 & 207,740 & 155, & 1,222 & ,224 \\
\hline
\end{tabular}
untuk mengetahui pengaruh tingkat inflasi terhadap return saham pada sektor property and real estate. Hasil dari uji statistik t-tes dapat dilihat pada tabel 2 sebagai berikut.

Tabel 2. Hasil Uji Statistik t-tes untuk tingkat inflasi terhadap return saham 
Hasil uji statistik untuk tingkat inflasi pada tabel 2 menunjukkan bahwa nilai thitung $=1,222<$ t-tes $=1,977$ atau $p$-value $=0,224>\alpha=0,05$ berarti $\mathrm{H}_{0}$ diterima. Dapat disimpulkan bahwa tingkat inflasi tidak mempunyai pengaruh yang signifikan terhadap return saham pada sektor property and real estate yang terdaftar pada Bursa Efek Indonesia periode 20122016.

\section{Pengaruh Tingkat Suku Bunga Terhadap Return Saham Pada Sektor Property and Real Estate \\ Uji statistik t-tes pada program SPSS}

22 for windows digunakan oleh peneliti untuk mengetahui pengaruh tingkat suku bunga terhadap return saham pada sektor property and real estate. Hasil dari uji statistik t-tes dapat dilihat pada tabel 3 sebagai

berikut.

Tabel 3. Hasil Uji Statistik t-tes untuk tingkat suku bunga terhadap return saham

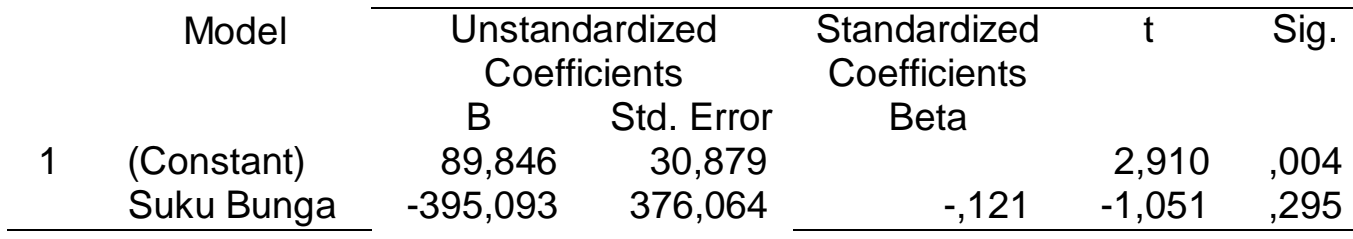

Hasil uji statistik untuk tingkat suku bunga pada tabel 3 menunjukkan bahwa nilai t-hitung $=-1,051<\mathrm{t}$-tabel $=1,977$ atau $\mathrm{p}$-value $=0,295>\alpha=0,05$ berarti $\mathrm{H}_{0}$ diterima. Dapat disimpulkan bahwa tingkat suku bunga tidak mempunyai pengaruh yang signifikan terhadap return saham pada sektor property and real estate yang terdaftar pada Bursa Efek Indonesia periode 2012-2016.
Pengaruh Kurs Valuta Asing Terhadap Return Saham Pada Sektor Property and Real Estate

Uji statistik t-tes pada program SPSS 22 for windows digunakan oleh peneliti untuk mengetahui pengaruh kurs valuta asing terhadap return saham pada sektor property and real estate. Hasil dari uji statistik t-tes dapat dilihat pada tabel 4 sebagai berikut.

Tabel 4. Hasil Uji Statistik t-tes untuk tingkat suku bunga terhadap return saham

\begin{tabular}{ccccc}
\hline Model & $\begin{array}{c}\text { Unstandardized } \\
\text { Coefficients }\end{array}$ & $\begin{array}{c}\text { Standardized } \\
\text { Coefficients }\end{array}$ & t & Sig.
\end{tabular}

\begin{tabular}{|c|c|}
\hline 1 & (Constant) \\
\hline & Kurs Valuta Asing \\
\hline
\end{tabular}

Hasil uji statistik untuk kurs valuta asing pada tabel 4 menunjukkan bahwa nilai $\mathrm{t}$-hitung $=-2,292>\mathrm{t}$-tabel $=1,977$ atau $p$-value $=0,023<\alpha=0,05$ berarti $\mathrm{H}_{0}$ ditolak. Dapat disimpulkan bahwa kurs valuta asing mempunyai pengaruh yang signifikan terhadap return saham pada sektor property and real estate yang terdaftar pada Bursa Efek Indonesia pada periode 2012-2016.

Pengaruh Tingkat Inflasi, Suku Bunga dan Kurs Valuta Asing Terhadap Return Saham Pada Sektor Property and Real Estate Pada Periode 2012-2016
Beta

Std. Error

30,879

$\begin{array}{rrr} & 2,910 & , 004 \\ -, 216 & -2,292 & , 023\end{array}$

Pengaruh tingkat inflasi, suku bunga dan kurs valuta asing terhadap return saham secara simultan dapat dilihat dari hasil analisis uji statistik $\mathrm{F}$ dan untuk besar pengaruhnya dilihat pada hasil model summary dengan program SPSS 22 for Windows. Uji statistik $\mathrm{F}$ ini menunjukkan analisis regresi berganda variabel bebas yaitu tingkat inflasi (X1), suku bunga (X2) dan kurs valuta asing (X3), memiliki pengaruh terhadap variabel terikat yaitu return saham (Y). Hasil analisis yang menunjukkan tingkat inflasi (X1), suku bunga (X2) dan kurs valuta asing (X3) memiliki pengaruh terhadap return saham, 
besar pengaruh dapat dilihat pada tabel $5 \quad$ sebagai berikut.

Tabel 5. Hasil Model Summary

\begin{tabular}{|c|c|c|c|c|}
\hline \multicolumn{5}{|c|}{ Model Summary } \\
\hline $\begin{array}{l}\text { Model } \\
1\end{array}$ & $\begin{array}{l}\mathrm{R} \\
, 294^{\mathrm{a}}\end{array}$ & $\begin{array}{r}\text { R Square } \\
086\end{array}$ & $\begin{array}{l}\text { Adjusted R } \\
\text { Square } \\
, 067\end{array}$ & $\begin{array}{l}\text { Std. Error of } \\
\text { the Estimate } \\
37,95194\end{array}$ \\
\hline
\end{tabular}

Berdasarkan tabel 5 dapat diketahui nilai Adjusted $R$ Square sebesar 0,067. Dapat disimpulkan besarnya pengaruh simultan tingkat inflasi, suku bunga dan kurs valuta asing terhadap return saham pada sektor property and real estate yang

terdaftar pada Bursa Efek Indonesia pada periode 2012 sampai 2016 sebesar 0,067 atau $6,7 \%$. Hasil analisis uji statistik $F$ dapat dilihat pada tabel 6 sebagai berikut.

Tabel 6. Hasil Uji F

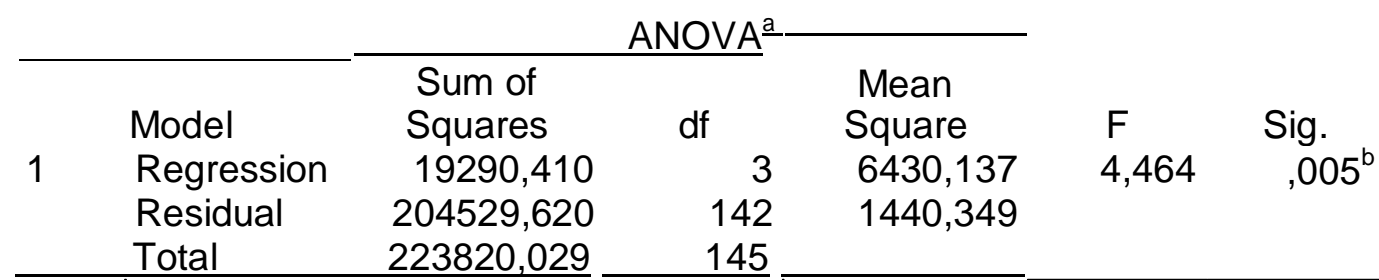

Berdasarkan tabel 6 dapat diketahui nilai F-hitung sebesar 4,464 dengan tingkat signifikan sebesar 0,005 sedangkan nilai F-tabel 2,67. Nilai Fhitung dibandingkan dengan nilai F-tabel menunjukkan bahwa F-hitung > F-tabel atau 4,464 $>2,67$ dan $p$-value $<\alpha$ atau $0,005<0,05$ sehingga menolak $\mathrm{H}_{0}$ dan menerima $\mathrm{H}_{\mathrm{a}}$. Demikian dapat disimpulkan tingkat inflasi, suku bunga dan kurs valuta

\begin{abstract}
asing secara simultan berpengaruh terhadap return saham pada sektor property and real estate yang terdaftar pada Bursa Efek Indonesia periode 2012 sampai 2016.
\end{abstract}

Berdasarkan pengelohan data, untuk mengetahui persamaan garis regresinya digunakan analisis koefisien beta dengan hasil yang dapat dilihat pada tabel 7 sebagi berikut.

Tabel 7. Hasil Perhitungan Koefisien Beta

\begin{tabular}{|c|c|c|c|c|c|c|}
\hline \multirow{5}{*}{1} & \multirow[b]{2}{*}{ Model } & \multicolumn{2}{|c|}{ Unstandardized } & Standardized & \multirow[b]{2}{*}{$\mathrm{t}$} & \multirow[b]{2}{*}{ Sig. } \\
\hline & & B & Std. Error & Beta & & \\
\hline & (Constant) & 89,846 & 30,879 & & 2,910 &, 004 \\
\hline & Inflasi & 253,950 & 207,740 & ,155 & 1,2 & 224 \\
\hline & Suku Bunga & $-395,093$ & 376,06 &,- 12 & $-1,0$ & 295 \\
\hline & Kurs Valuta Asing &,- 005 &, 002 &,- 216 & $-2,292$ &, 023 \\
\hline & $\begin{array}{l}\text { Dersamaan garis reg } \\
\text { untuk menggamba } \\
\text { t inflasi, suku bunga } \\
\text { terhadap return sah } \\
\text { rty and real estate } \\
\text { Bursa Efek Indones } \\
\text { a } 2016 \text { sebagai berik }\end{array}$ & $\begin{array}{l}\text { ang dapat } \\
\text { pengaruh } \\
\text { kurs valuta } \\
\text { ada sektor } \\
\text { terdaftar } \\
\text { iode } 2012\end{array}$ & $\begin{array}{l}\mathrm{Y}=8 \mathrm{~S} \\
0 \\
\text { Keterai } \\
\mathrm{Y}=R \\
\mathrm{X} 1=\mathrm{T} \\
\mathrm{X} 2=\mathrm{T} \\
\mathrm{X} 3=\mathrm{K}\end{array}$ & $\begin{array}{l}9,846+253,9 \\
, 005 X_{3} \\
\text { ngan: } \\
\text { ieturn Saham, } \\
\text { ingkat Inflasi, } \\
\text { ingkat Suku Bu } \\
\text { urs Valuta Asir }\end{array}$ & $x_{1}-39$ & $093 X_{2}$ \\
\hline
\end{tabular}


Persamaan garis regresi tersebut mengartikan bahwa pada saat $X_{1}$ (inflasi), $\mathrm{X}_{2}$ (suku bunga) dan $\mathrm{X}_{3}$ (kurs valuta asing) bernilai 0 atau konstan, maka nilai $Y$ (Return Saham) sebesar 89,846. Setiap ada kenaikan variabel bebas baik $X_{1}$ (inflasi), $X_{2}$ (suku Bunga) dan $X_{3}$ (kurs valuta asing), sebesar satu satuan maka akan meningkatkan $Y$ (Return Saham) sebesar nilai koefisien beta masingmasing variabel bebas dikalikan dengan besarnya kenaikan yang terjadi.

\section{Pembahasan}

Berdasarkan hasil penelitian yang dilakukan mengenai pengaruh tingkat inflasi, suku bunga dan kurs valuta asing terhadap return saham pada sektor property and real estate yang terdaftar pada Bursa Efek Indonesia periode 2012 sampai 2016, diketahui bahwa secara parsial tingkat inflasi tidak berpengaruh signifikan terhadap return saham pada sektor property and real estate di BEI pada periode 2012 sampai 2016. Hal ini ditunjukan dari hasil analisis uji signifikansi dengan uji $\mathrm{t}$ diperoleh tingkat inflasi $\mathrm{t}$ hitunh $=1,222<\mathrm{t}$-tabel $=1,977$ dengan tingkat signifikansi sebesar $0,224>\alpha=$ 0,05 . Hasil penelitian ini sesuai dengan temuan Satria (2016) yang menunjukkan bahwa tingkat inflasi tidak berpengaruh signifikan terhadap return saham. Inflasi yang tinggi mengakibatkan penurunan daya beli konsumen. Disamping itu inflasi yang terlalu tinggi juga dapat mengakibatkan penurunan pendapatan riil investor dari investasinya. Bagi perusahaan inflasi akan berdampak pada penjualan dan biaya produksi perusahaan tersebut. Inflasi yang terjadi selama periode penelitian berada pada level di bawah $10 \%$ jika dilihat dari sudut pandang investor dinilai wajar dan stabil, serta bukan merupakan faktor penentu atau penjelas perubahan return saham, sehingga investor lebih memperhatikan bagaimana cara perusahaan menghasilkan laba yang tinggi agar menghasilkan return yang tinggi bagi para investor. Investor juga yakin bahwa perusahaan memiliki strategi khusus dalam menghadapi inflasi di Indonesia, sehingga besar kecilnya inflasi tidak memengaruhi laba yang akan diperoleh oleh perusahaan. Strategi khusus yang dapat diterapkan perusahaan agar kegiatan bisnis perusahaan tetap berlangsung antara lain, menekan biaya produksi, biaya operasional dan pemasaran yang tidak perlu. Maka dari itu, walaupun setiap tahun terjadi inflasi sektor property and real estate tetap mampu memperoleh laba dan investor tetap memperoleh return atas investasi di perusahaan tersebut. Berdasarkan alasan di atas, investor dalam pengambilan keputusan investasinya tidak terpengaruh oleh adanya perubahan inflasi yang terjadi setiap tahun selama tingkat inflasi tersebut masih dianggap wajar dan stabil.

Pengaruh tingkat suku bunga secara parsial tidak berpengaruh signifikan terhadap return saham pada sektor property and real estate di BEI pada periode 2012 sampai 2016, hal ini ditunjukan dari hasil analisis uji signifikansi dengan uji t diperoleh tingkat suku bunga t-hitung $=-1,051<\mathrm{t}$-tabel $=1,977$ dengan tingkat signifikansi sebesar 0,295 > $\alpha=$ 0,05 . Hal ini mencerminkan bahwa tingkat suku bunga yang ditentukan oleh Bank Indonesia tidak berpengaruh terhadap peningkatan atau penurunan tingkat return saham yang dalam hal ini diukur dengan closing price. Hasil penelitian ini sejalan dengan hasil penelitian oleh Sri Suyati (2015) yang mendukung bahwa tingkat suku bunga tidak berpengaruh terhadap return saham. Samsul (2006) mengungkapkan bahwa investor dalam melakukan analisis saham suatu perusahaan cukup dengan membandingkan modal internal dengan modal pinjaman dari luar perusahaan untuk mengetahui kondisi suatu perusahaan. Jika modal internal lebih besar dari pada modal pinjaman, maka dapat dikatakan bahwa perusahaan tersebut sehat dan tidak mudah bangkrut, hal ini juga selaras dengan proyeksi nilai sahamnya di pasar modal. Kinerja keuangan sektor propert and real estate berdasarkan uraian pada laporan tahunan (annual report) menunjukkan bahwa sebagian besar perusahaan dalam kondisi baik. Hal ini dapat diketahui dari presentase ekuitas yang lebih besar 
dibandingkan dengan liabilitas, terjadi peningkatan rasio lancar (current ratio), dan perusahaan selalu memperoleh laba usaha. Selain itu, guna meminimalkan risiko terkait suku bunga, perusahaan mengombinasikan suku bunga mengembang dengan suku bunga tetap. Hal ini mengindikasikan bahwa keuangan peruisahaan yang berkaitan dengan kredit sedang dalam kondisi baik sehingga investor dalam melakukan transaksi saham tidak terpengaruh oleh perubahan tingkat suku bunga, begitu pun dengan tingkat perolehan return saham pada perusahaan tersebut. Strategi-strategi yang dilakukan perusahaan tersebut dinali mampu menjaga perolehan laba sektor property and real estate di tengah perubahan tingkat suku bunga, sehingga investor untuk menanam saham di sektor property and real estate tetap tinggi.

Kurs valuta asing secara parsial berpengaruh signifikan terhadap return saham pada sektor property and real estate di BEI pada periode 2012 sampai 2016, hal ini ditunjukan dari hasil analisis uji signifikansi dengan uji t diperoleh kurs valuta asing t-hitung $=-2,292>\mathrm{t}$-tabel $=$ 1,977 dengan tingkat signifikansi sebesar $0,023<\alpha=0,05$. Hasil penelitian ini sesuai dengan temuan Sri Suyati (2015) yang menunjukkan bahwa kurs valuta asing berpengaruh signifikan terhadap return saham. Tandelilin (2010:344) mengatakan bahwa nilai kurs berdampak positif terhadap return saham. Berdasarkan laporan tahunan yang diterbitkan oleh perusahaan, dapat diketahui bahwa banyak sektor property and real estate melakukan impor bahan baku, sehingga biaya produksinya sangat dipengaruhi oleh pergerakan kurs valuta asing. Oleh karena itu, investor menganggap bahwa fluktuasi kurs valuta asing yang tinggi dapat berakibat pada tingkat pendapatan perusahaan serta return yang akan diperoleh investor. Investor dalam mengambil keputusan atas kepemilikan saham pada sektor property and real estate tentu memperhtikan pergerakan kurs valuta asing dari tahun ke tahun. Depresiasi kurs valuta asing dapat menaikkan perolehan laba atas ekspor perusahaan, di sisi lain juga dapat menurunkan perolehan laba perusahaan jika perusahaan melakukan impor dalam jumlah besar. Oleh karena sektor. Oleh karena sektor property and real estate memiliki tingkat impor yang tinggi, maka pada saat nilai rupiah terus mengalami depresiasi terhadap dolar Amerika secara konstan, banyak investor akan mengambil posisi jual yang mengakibatkan permintaan terhadap saham sektor property and real estate menurun dan berdampak pada return saham perusahaan tersebut.

Hasil penelitian mengenai pengaruh tingkat inflasi, suku bunga dan kurs valuta asing secara simultan terhadap return saham pada sektor property and real estate di BEI pada periode 2012 sampai 2016, menunjukkan bahwa secara simultan tingkat inflasi, suku bunga dan kurs valuta asing berpengaruh signifikan terhadap return saham pada sektor property and real estate di BEI pada periode 2012 sampai 2016. Hal ini dapat dilihat dari hasil F-hitung $=4,464>\mathrm{F}$-tabel $=2,67$ dengan signifikansi sebesar 0,005 $<0,05$. Besarnya pengaruh simultan tingkat inflasi, suku bunga dan kurs valuta asing terhadap return saham pada sektor property and real estate di BEI pada periode 2012 sampai 2016 sebesar 0,067 atau $6,7 \%$. Hasil regresi linier berganda diperoleh persamaan $\mathrm{Y}=89,846+$ $253,950 X_{1}-395,093 X_{2}-0,005 X_{3}$.

\section{SIMPULAN DAN SARAN Simpulan}

Berdasarkan hasil penelitian dan pembahasan, maka dapat disimpulkan sebagai berikut. Pertama inflasi tidak berpengaruh signifikan terhadap return saham pada sektor property and real estate yang terdaftar pada Bursa Efek Indonesia periode 2012-2016. Hal ini ditunjukan dari hasil analisis t-tes yang menunjukkan bahwa nilai t-hitung $=1,222$ $<\mathrm{t}$-tabel $=1,977$ atau $\mathrm{p}$-value $=0,224>$ 0,05 . Kedua suku bunga tidak berpengaruh signifikan terhadap return saham pada sektor property and real estate yang terdaftar pada Bursa Efek Indonesia periode 2012-2016. Hal ini ditunjukan dari hasil analisis t-tes yang menunjukkan bahwa nilai t-hitung $=-1,051$ 
$<$ t-tabel $=1,977$ atau $\mathrm{p}$-value $=0,295>$ 0,05 . Ketiga kurs valuta asing berpengaruh signifikan terhadap return saham pada sektor property and real estate yang terdaftar pada Bursa Efek Indonesia periode 2012 sampai 2016. Hal ini ditunjukan dari hasil analisis t-tes yang menunjukkan bahwa nilai t-hitung $=-2,292$ $>$ t-tabel $=-1,977$ atau $\mathrm{p}$-value $=0,023<$ 0,05 . Keempat inflasi, suku bunga dan kurs valuta asing berpengaruh signifikan terhadap return saham pada sektor property and real estate yang terdaftar pada Bursa Efek Indonesia periode 20122016. Hal ini ditunjukan dari hasil analisis F-tes yang menunjukkan F-hitung $=4,464$ $>$ F-tabel $=2,67$ atau $p$-value $=0,005<$ 0,05 .

\section{Saran}

Berdasarkan simpulan diatas, maka dapat dikemukakan beberapa saran sebagai berikut. Bagi pihak investor yang ingin meningkatkan return sahamnya perlu memperhatikan tingkat kurs valuta asing mengingat variabel tersebut memiliki dampak yang signifikan terhadap pergerakan return saham. Berdasarkan pada $R^{2}$ yang bernilai kecil yaitu hanya sebesar 6,7 persen yang memiliki pengaruh terhadap model dan sisa sebesar 93,3 persen dijelaskan oleh variabel lain diluar model. Maka, disarankan untuk penelitian selanjutnya agar menambahkan variabel lain yang mempengaruhi return saham serta menambah periode waktu penelitian sehingga dapat memperoleh hasil yang lebih maksimal.

\section{DAFTAR PUSTAKA}

Cahyono. 2000. Dasar-dasar Analisis Kinerja Keungan. Edisi Kedua. Cetakan Pertama. Jakarta: TPWI.

Ghozali, Imam. 2011. Aplikasi Analisis Multivariate dengan Program SPSS. Edisi Kelima. Semarang: Universitas Diponogoro.

Halim, Abdul. 2005. Analisis Investasi. Edisi ke-2. Jakarta: Salemba Empat.
Hartono, Jogiyanto. 2008. Teori Portofolio dan Analisis Investasi. Yogyakarta: BPFE-UGM.

2009. Teori Portofolio dan Analisis Investasi. Edisi Keenam. Cetakan pertama. Yogyakarta: PT.BPEE.

2010. Teori Portofolio dan Analisis Investasi. Edisi Keenam, Yogyakarta: BPFE.

Kasmir. 2008. Bank dan Lembaga Keuangan Lainnya. Edisi Revisi 8. Jakarta: PT Raja Grafindo Persada.

. 2005. Bank dan Lembaga Keuangan Lainnya. Jakarta: PT Raja Grafindo Persada.

Samsul, Mohammad. 2006. Pasar Modal dan Manajemen Portofolio. Jakarta: Penerbit Erlangga.

Samuelson, Paul A \& Nordhaus, Wiliam D. 2001. IImu Mekro Ekonomi. Jakarta: PT. Media Edukasi.

Satria, Wiradharma. 2016. Pengaruh Tingkat Suku Bunga, Tingkat Inflasi, Nilai Kurs Rupiah dan Produk Domestik Bruto Terhadap Return Saham. E-Jurnal Manajemen Unud, 5 (6): 3412-3414

Sugiyono. 2012. Metode Penelitian Kuantitatif Kualitatif dan R\&D. Bandung: Alfabeta.

Sukirno, Sadono. 2008. Teori Pengantar Makroekonomi edisi 3. Jakarta: PT Raja Grafindo Persada.

Sunariyah. 2006. Pengantar Pengetahuan Pasa Modal. Yogyakarta: UPP STIM YKPN.

Suta. 2000. Menuju Pasar Modal Modern. Jakarta : Yayasan SAD SATRIA BHAKTI.

Suyati, Sri. 2015. Pengaruh Inflasi, Tingkat Suku Bunga dan Nilai Tukar Rupiah/US Dollar Terhadap Return Saham Properti yang Terdaftar di Bursa Efek Indonesia. Serat Acitya Jurnal IImiah UNTAG Semarang. 4 (3):

$79-82$ 
Tandelilin, Eduardus. 2010. Analisis Investasi dan Manajemen Portofolio. Edisi Pertama. Yogyakarta: BPFE.

Wibowo, Edy Agung. 2012. Aplikasi Praktis SPSS dalam Penelitian. Edisi Pertama. Yogyakarta: Gava Media.

Wirawan, Nata. 2002. Cara Mudah Memahami Statistik 2 (Statistik Inferensia) Untuk Ekonomi dan Bisnis, Edisi Kedua. Denpasar: Keraras Media 